\title{
The Exploration and Practice of Multi-Subject Implementation Mode in Postgraduate Entrance Education
}

\author{
Ming $\mathrm{He}$ \\ School of Information Science and Engineering \\ Wuhan University of Science and Technology \\ Wuhan, China
}

\begin{abstract}
Entrance education is an important link in the postgraduates' ideological and political education and it plays an important role in the process of postgraduates' holistic education. We should seek and jointly participate in multi-subjects by virtues of functional strengths of each subject in the process of management education and service education, construct the basic framework and implementation mode of multi-subjects in postgraduates' entrance education, and explore the implementation paths of multi-subject participation.
\end{abstract}

Keywords-Postgraduate entrance education; multi-subjects mode

\section{INTRODUCTION}

Entrance education, as the "first class" in the process of postgraduate holistic education, is an important component of postgraduate innovation education and talent cultivation and a key link in the postgraduates' ideological and political education. Postgraduate entrance education not only can acquaint freshmen with the theory of university on school management, thoroughly understand discipline orientation and grasp the laws of growth and success, but also be good for freshmen realize roles exchange, set up study objective and finish school.

In general cases, postgraduate entrance education is individually the responsibilities of student affairs group for implementation and the teacher strength is temporarily composes of counselor, teacher in charge and department teachers, the theme is limited in regular educations of school discipline and entrance adaption, the subject of education is single lacking systematic, educational teachers are short of science and the contents of education are thin and lack of hierarchy[1]. Scientifically exploring new mode of postgraduate entrance education, effectively carrying out postgraduate entrance education have an important significance in deepening postgraduate education reform and promoting long-term development of postgraduate education.

\section{THEORETICAL EXPLORATION OF MULTI-SUBJECTS}

\section{A. Basic Frame of Multi-Subjects}

Postgraduate entrance education system includes educational subject, educational objective, educational method and effect examination, of which, the most key factor is the implementation subject, which is the spirit and soul of the whole entrance education system. According to departments related to entrance education, related subjects found through systemic analysis are: college party school, propaganda department, career center, mental health center, postgraduate work department and security department etc. only carrying out entrance education facing postgraduate groups from different views through integrating these subjects, can provide systemic, comprehensive, scientific and abundant educational contents.

The implementation subjects of postgraduate entrance education formed by said different functional departments shall coordinate with each other, innovate new educational modes, so as to build integral system of mutual communication information, mutual promotion, joint development and effective operation, and its basic frame is as shown in "Fig. 1".

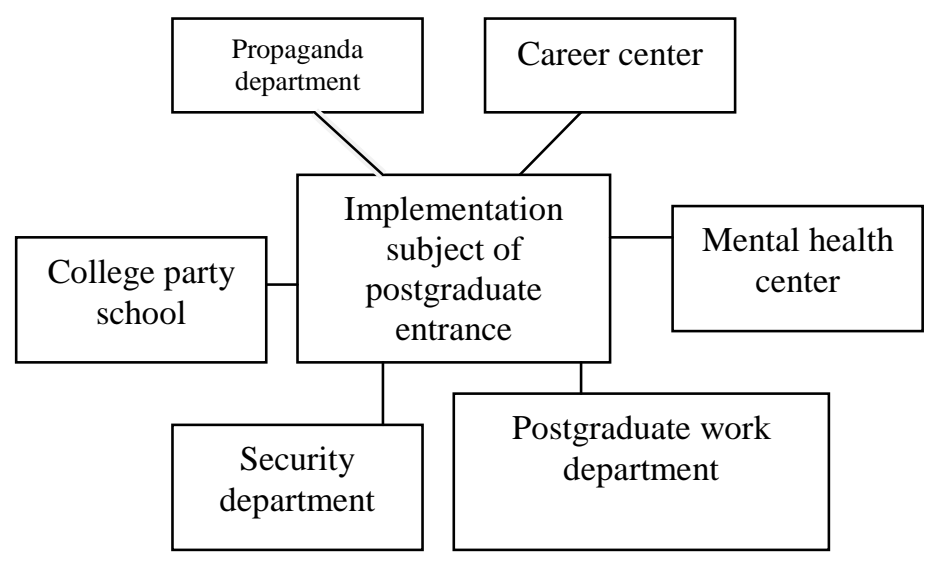

Fig. 1. Basic frame of multi-subjects 


\section{B. Implementation Mode of Multi-Subjects}

Implementation mode of multi-subjects refers to the entrance education mode for postgraduate groups, which is participated, organized, planned and implemented by multiple subjects, fully mobilizing the implementation subjects of multiple functional departments to utilize the functional strengths of different departments in the aspects of management education and service education. This mode aims at changing the previous mode counselor leading student team to carry out entrance education singly to mode depending on the collaboration of each functional department.

There are many contents having typical educational significance in postgraduate entrance education, such as ideal and belief education, campus cultural education, career education etc. and each functional department takes the responsibilities of building different contents to different themes, forms brand education content, continuously and intensively carry out in the postgraduate freshman, make the postgraduate entrance education more have comprehensiveness, systematicness and scientificity. The subjects of each functional department shall carry out collaboratively, innovate the services and form the postgraduate entrance education mode with distinguished characteristics, as shown in "Fig. 2".

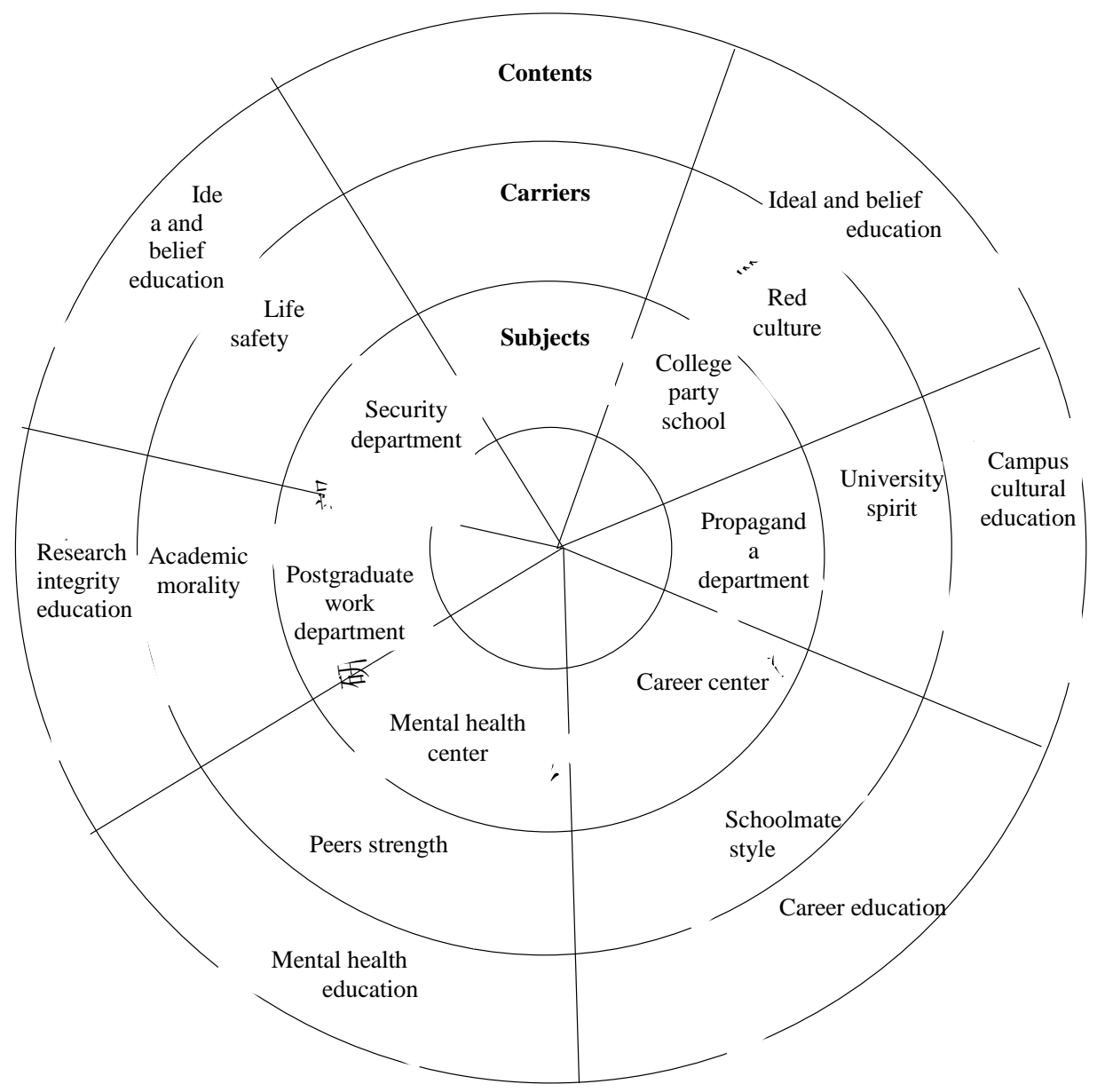

Fig. 2. Implementation mode of multi-subjects

\section{SCIENTIFIC Practice OF MUlti-SubJeCts}

\section{A. Red Culture Experience: College Party School Carry out Ideal and Belief Education as Subject}

Red culture is the revolutionary theory formed by majority of the Chinese people led by Chinese Communist Party in the fighting and constructional practice and traditional culture formed by their revolutionary spirit, and is the outcome from the combination of Chinese revolutionary historical practice and Chinese historical culture, including revolutionary relic, heritage museum, historical monument, martyrs' park and other material carriers as well as the spiritual substance of patriotism, serving for people, hard work and plain living and no afraid of sacrifice formed in revolutionary war ages and the constructional practice of socialist, which is strong edification rendering and practically educational. 
Experience red culture in entrance education, practically carry out ideal and belief education taking college party school as implementation subject. Firstly, lead the postgraduate groups to understand the conditions of people, party and nation, recognize own shouldered historical mission and social responsibility, firm the political conviction of loving party, nation and socialist, fix the socialist core value and strengthen national self-confidence and social pride. Secondly, fully play the political guidance function, character education and practical participation function [2] of red culture, lead the postgraduate groups to experience the red revolution resources in Hubei area deeply, utilize red culture to educate postgraduates in new generation, promote the group ideology and morality quality and urge group to set up correct learning objective and great worldly ideal.

\section{B. Cultivation of University Spirit: Carry out Campus Culture Education Taking Propaganda Department as Subject}

University spirit is the deep metal structure and inner faith accumulatively formed by teachers and students in university on the basis of value cognition, which plays decisive role for teachers and students in university conducting judgment and selection ofvalue as well as establishing value orientation and pursuit. University spirits include academic spirit of pursuing truth, self-consciousculture critical spirit, rational free spirit and strong humanistic spirit [3], campus culture is the result deposited in the development of university for long term and the external manifestation form of university spirit. Highqualified campus culture has significant osmosis function on building the spirit, mental and characteristics of postgraduate group. Completely play the leading and edification functions of university spirit, urge postgraduates to rediscover themselves, enrich themselves and perfect themselves in abundant and colorful campus culture, set up correct value objectives, build complete personality, so as to promote the overall harmonious development of growth in spirit and success in major.

Experience university spirit in entrance education link, practically carry out ideal and belief education taking propaganda departments of college party school as implementation subject. Firstly, lead postgraduates to strengthen their study and understanding to university spirit, urge them to understand the core, historical traditional, spiritual quality, value pursuit and other demands of spiritual culture of university culture, promote postgraduates deeply perceive the history of school running and theory of school running, build school loyalty and self-cognition as well as cultivate school-loving consciousness and school-respecting feelings.

\section{Exhibition of Schoolmate Meeting: Carry out Career Education Taking Career Center as Subject}

Universities and colleges continuously cultivate youth talents with culture, quality and objectives, and after entering the society, they will promote the healthy development of society, and form vast schoolmate network in various industries, converting the knowledge results of universities into labor productivity, serving the society and bringing benefit to people. University can completely play the unique function of schoolmate resource in the career education of freshmen, and effectively utilize schoolmate resource to carry out career education.

Experience schoolmate style in entrance education link, practically carry out career education taking the career center of university as implementation subject. University can analyze the schoolmate characteristics from the factors of career environment, positioning, social role and professional conversation, and establish case library of career education. Firstly, excellent schoolmate affairs have education demonstration effect on the postgraduates' career planning education [4], which can make freshmen establish favorable career ideal and objective at the beginning of entering school and establish correct specialty thought. Secondly, the growth experiences of outstanding schoolmates have guidance and leading effect on the postgraduates' career planning [4], inviting excellent schoolmate as the off-campus tutor of career planning to conduct education of employment view and jobselection view meeting the social practice, makes the postgraduates have more correct positioning of employment and job-selection.

\section{Demostration of Peers Strength: Carry out Mental Health Education Taking Mental Health Center as Center}

The original meaning of peer education refers to the education of people having same background or common world due to some reason jointly share information, conception or behavior skills for realizing educational objectives. Carrying out peers education in postgraduate groupmainly refers to fully playing the drive role of excellent peers group, helping surrounding students on study, life and mental all out, making both parties mutually care and assist each other to realize association methods of having complementary advantages and mutual growth.

Experience peers' strength in entrance education link, practically carry out mental health education taking mental health center as implementation subject.Peer counselling mode, as a new counseling mode of developing students' potential, fully motivating students' subjectivity and emphasizing students'mechanism of helping each other action, highlights its advantages of wide related objectives, discovering problem in time, simple and easy operation as well as rapid and obvious effect [5]. Taking peers strength as an example is good for urging student exchange equally, strengthening infection of education; increasing counsellor's management channels, providing pertinence of education as well as increasing the self-management skills of excellent peers and expanding the influence of education.

\section{E. Observing Academic Morality: Carry out Honesty Education Taking Postgraduates Work Department as Subject}

Academic morality refers to the morality standard and standard of behavior for inner scientific community and scientific workers in process of conducting science research and treating achievements in scientific research, for specific performance of the value pursuit and ideal personality [6] of 
science workers undertaking science and technical activities. On the hand of scientific objective, take the principle of pursuing acquaintance of truthfulness and the overall interest of social development of human being; on the hand of scientific attitude, look for the truth and be practical without practice fraud and do not breach the rational conscience and sense of moral responsibility the science workers deserved for pursuing personal fame and gain.

Experience academic morality in entrance education link; practically carry out research integrity education taking postgraduate work department of college party school as implementation subject.Postgraduate studying in university is embodied in the academic inheritance and knowledge innovation in most cases, they are the main force of research work and discipline construction. Research integrity is the basic research quality postgraduate require having, conduct academic standard education to freshmen, lead postgraduate groups to abide by academic integrity, complete academic personality, maintain academic dignity, make the freshmen further recognize the significance of complying with academic morality and maintaining academic standard, so as to promote the self-discipline consciousness of academic morality, academic responsibility consciousness and academic innovative consciousness of freshmen, which has significant meaning to form favorable academic atmosphere and research ethos.

\section{F. Life Safety Experience: Carry out Security Education Taking Security Department as Subject}

The foundation of safety education is life education, and the initial problem of safety education is to ensure life safety and teaching students mastering knowledge of emergency and disaster-prevention. Cultivating freshmen the consciousness of knowing life, cherishing life and reverence for life are the important guarantee for universities and colleges to conduct safety education work. At the same time of strengthening the feeling and experience to life, recall postgraduates' treasuring and loving of life, so as to urge the safe and healthy growth [7] of postgraduate.

Experience life bailment in entrance education link; practically carry out security education taking security department of the university as implementation subject. Develop teaching mode of experience type life education, construct the life education system of "life and health education, life and safety education, life and growth education, life and value education as well as life care education", conduct exploration and practice through the educational channels of educational base, classroom potential, mental counselling, life safety, quality expansion, , study typical, role play, campus culture activities and social practice, preach the common sense of emergency treatment, raise the students' safety precautions, emergency treatment and coping skills and capacity of self-protection, and establish active and effective life crisis interventional mechanism, lead postgraduates to cherish life, love life and continuously improve the quality and value of life.

\section{CONCLUSION}

In order to well play and utilize the leading function of postgraduate entrance education and cultivate interdisciplinary talents having both morality quality and theoretical conservation, this article explores the basic frame and implementation mode of the multi-subjects of postgraduate entrance education. And it utilizes the functional strengths of each subjects in management education and service education and explores the implementation paths participated by multi-subjects and provides reference and examples for the multi-subjects coordinative education of postgraduate entrance education.

\section{REFERENCES}

[1] Ming He. Analysis of Problems in Postgraduate Entrance Education and Researchon its System Constructions in the New Era[C]. // 2nd International Conference on Humanities and Social Science Research. 2016: 419-422.

[2] Wang Ping. Arouse the Correct Ideal and Belief of Undergraduates with Red Culture [J]. Folk Art and Literature, 2012, (23): 294-295.

[3] Huang Aihua. University Spirit, Campus Culture and Ideological and Political Education[C]. 2012college quality-oriented education research seminar of China Association of Higher Education and quality-oriented education and university spirit high-level forum proceedings. 2012: 2629.

[4] Cui Gang. Simply Analysis on the Function of Schoolmate in the Process of Undergraduates' Career Planning Education $[\mathrm{J}]$. Inspection, 2014, (8): 192.

[5] Li Mingzhong. Improvement of the Effectiveness of Peer Counselor Mode and Undergraduate Mental Health Education [J].Heilongjiang Researches on Higher Education, 2011, (8):4-8.

[6] Gu Lina, Liu Jiaji, Chen Zhihua.Primary Exploration of University Scientific Morality and Academic Standard [C]. proceedings of education of engineering graduate student work seminar of No. 26 national postgraduate school 2012: 282-285.

[7] Yang Yong, Qin Yan. Analysis on Experiential Life Education under the Vision Field of Undergraduate Safety Education [J].Journal of Chongqing College of Electronic Engineering, 2012, 21 (2): 107-110. 